\title{
PENGEMBANGAN LEMBAR KERJA PESERTA DIDIK UNTUK MENILAI KECENDERUNGAN BERPERILAKU KONSERVASI KURA-KURA
}

\author{
Dwi Martha Trisna ${ }^{1 *}$, Aceng Ruyani ${ }^{1}$, dan Yennita ${ }^{1}$ \\ ${ }^{1}$ Program Studi Pendidikan Biologi, Fakultas Keguruan dan Ilmu Pendidikan, Universitas Bengkulu \\ Email:trisnadwimartha@yahoo.com
}

\begin{abstract}
Abstrak
Tujuan penelitian ini adalah menganalisis kelayakan pengembangan LKPD konservasi kura-kura pada materi pembelajaran interaksi makhluk hidup dengan lingkungan dan menilai kecenderungan berperilaku konservasi kura-kura peserta didik. Jenis penelitian adalah Research and Development $(R n D)$ yaitu penelitian untuk mengembangkan suatu produk. Metode penelitian adalah kuantitatif deskriptif. Penilaian perilaku konservasi peserta didik menggunakan angket konservasi kura-kura diberikan pada pembelajaran dengan strategi indoor-outdoor-indoor. Hasil penelitian menunjukkan bahwa validasi pengembangan LKPD dengan persentase $80-86,67 \%$, memiliki kriteria "sangat valid" dan terjadi peningkatan perilaku konservasi kura-kura peserta didik sebesar 5,46 \%. Dari hasil penelitian dapat disimpulkan bahwa LKPD pada materi interaksi makhluk hidup dengan lingkungan sangat layak diujicoba dan efektif untuk meningkatkan kecenderungan berperilaku konservasi kurakura bagi peserta didik.
\end{abstract}

Kata kunci: Kura-kura sumatera, Lembar Kerja Peserta didik (LKPD), RnD

\begin{abstract}
The purpose of this study is to analyze the feasibility of developing turtle conservation student worksheet on learning materials interaction of living things with their environment and assessing the tendency of turtle conservation behavior for students. Type of research is Research and Development. The research method is quantitative descriptive. Assessment of turtle conservation behavior for students using a turtle conservation questionnaire is given on learning with indooroutdoor-indoor strategies. The result showed that LKPD validation with percentage of $80-86,67 \%$ have criterion "very valid" and there is increase of turtle conservation behavior for students equal to $5,46 \%$. The conclusion of the results of this research is student worksheet on the material interaction of living things with their environment is very worthy to be tested and effective to increase the tendency of turtle conservation behavior for students.
\end{abstract}

Keywords: The turtle of Sumatera, Student worksheet, RnD 


\section{PENDAHULUAN}

Indonesia menjadi unggulan dunia dalam hal keanekaragaman jenis. Indonesia diperkirakan memiliki tidak kurang dari 47 tipe ekosistem alami dan kekayaan jenis tumbuhan, hewan dan mikrobia. Indonesia ternyata menjadi habitat $16 \%$ reptilia dan amfibia yang ada di dunia (Astirin, 2000). Istilah yang digunakan untuk kelompok hewan amphibi dan reptil menurut Thayer (2001) dalam Qurniawan (2010), disebut herpetofauna. Ilmu yang mempelajari herpetofauna dinamakan herpetologi. Amphibi adalah kelompok hewan yang hidup di dua alam, sedangkan reptil adalah kelompok hewan melata. Kura-kura adalah hewan reptil yang mudah dikenal dengan keberadaan karapaks sebagai pembungkus badannya, yang bertindak sebagai perisai untuk menghadapi ancaman musuh. Pada kura-kura yang menonjol keluar hanya kaki, kepala dan ekornya.

Menurut Kursini (2005), kura-kura merupakan salah satu fauna yang keragaannya banyak ditemukan di provinsi Bengkulu. Di area konservasi Universitas Bengkulu (UNIB) telah diidentifikasi dan dikoleksi sepuluh dari 15 jenis kura-kura Sumatera. (Wiryono dkk, 2016). Iskandar (2000), menyatakan kura-kura rentan mengalami kepunahan. Pertumbuhan kurakura sangat lamban, diperkirakan lebih dari 4 sampai 10 tahun untuk mencapai ukuran dewasa. Selain itu kura-kura air tawar dengan ukuran tubuhnya yang kecil hanya bertelur 24 butir dalam satu bulan, selain itu menurut Rahman, (2008) penyebaran kura-kura terbatas serta tingginya permintaan hewan ini dari China, Jepang, dan negara-negara Eropa lainnya untuk dijadikan bahan konsumsi, membuat perburuan secara berkelanjutan untuk diperdagangkan. Perburuan ini dianggap sebagai faktor penting dalam menurunkan tingkat populasi kura-kura.

Menurunnya jumlah kura-kura dapat diatasi dengan upaya perlindungan dan pencegahan terhadap spesies kura-kura. Perlindungan dan pencegahan dapat mengembalikan keseimbangan ekosistem terutama dalam rantai makanan dan jaringjaring makanan. Konservasi terhadap kurakura dapat dilakukan oleh masyarakat. Salah satu upaya yang dapat dilakukan adalah dengan meningkatkan dan mengkampanyekan kepedulian terhadap spesies kura-kura melalui dunia pendidikan (Wiryono dkk, 2016). Permasalahpermasalahan sosial seperti perilaku masyarakat sering menjadi hambatan dalam melakukan kegiatan konsevasi kura- kura, sehingga pendekatan melalui jalur pendidikan sangat penting untuk dilakukan dalam menunjang program tersebut. (Wiryono dkk, 2016).

Anggraini dkk (2017) telah mengembangkan modul pendidikan konservasi kura-kura bagi siswa SMP, di dalam modul tersebut terdapat LKPD yang dapat digunakan untuk melihat perilaku konservasi siswa. Berdasarkan hasil analisis bahan ajar yang telah dilakukan, modul yang dikembangkan oleh tim PEER Project S2 Pendidikan IPA Universitas Bengkulu masih memiliki kekurangan dan kelemahan, yakni LKPD masih sangat sederhana dan kurang menarik perhatian peserta didik. Kurang menariknya LKPD sebelumnya dapat dilihat dari tampilan LKPD yang masih berupa putih polos, belum memiliki cover, dan tujuan pada LKPD masih ada yang merujuk pada materi keanekaragaman hayati. Selain itu dari hasil wawancara dengan guru IPA di SMP 17 Kota Bengkulu, LKPD tentang konservasi kura-kura sumatera belum pernah digunakan oleh siswa pada saat proses pembelajaran di sekolah.

Dalam penelitian ini, akan dilakukan uji coba LKPD yang terdapat di dalam modul menggunakan kegiatan pembelajaran IndoorOutdoor-Indoor (IOI). Melalui pembelajaran $\mathrm{IOI}$ ini, akan diukur mengenai kecenderungan perilaku konservasi siswa dari hasil penggunaan LKPD saat pembelajaran. melalui kegiatan pembelajaran $\mathrm{IOI}$ dan penggunaan LKPD berbasis konservasi, diharapkan dapat membuat proses pembelajaran menjadi lebih bermakna serta berpengaruh positif terhadap kecenderungan perilaku konservasi siswa. 


\section{METODE}

Penelitian ini menggunakan metode Research and Development (R\&D). Subyek penelitian ini adalah peserta didik kelas VII A SMPN 17 Kota Bengkulu. Prosedur penelitian terdiri dari 6 tahap yakni: 1) Potensi dan masalah; 2) Mengumpulkan informasi; 3) Desain produk; 4) Validasi desain; 5) Perbaikan desain ; 6) Uji coba produk. Teknik pengumpulan data menggunakan angket perilaku konservasi yang diberikan pada awal pembelajaran indoor 1 dan akhir pembelajaran indoor 2. Perhitungan data validasi LKPD dihitung menggunakan rumus :

$$
\text { persentase }=\frac{\text { jumlah hasil pengkuran data }}{\text { skor maksimal }} \times 100 \text { persen }
$$

Data kuantitatif yang diperoleh diubah menjadi data kualitatif dengan memperhatikan panduan tabel kriteria penilaian hasil validasiyang dapat dilihat pada Tabel 1.

Tabel 1. Kriteria Penilaian Hasil Validasi

\begin{tabular}{cc}
\hline Persentase & Kriteria \\
\hline $81 \%-100 \%$ & Sangat valid \\
$61 \%-80 \%$ & Valid \\
$41 \%-60 \%$ & Cukup valid \\
$21 \%-40 \%$ & Kurang valid \\
\hline
\end{tabular}

Perhitungan persentase skor angket perilaku konservasi peserta didik dihitung menggunakan rumus:

$$
\mathrm{p}=\frac{\sum \mathrm{xi} .100}{\sum \mathrm{xn}}
$$

Keterangan:

$\mathrm{p} \quad=$ persentase yang dicari

$\Sigma \mathrm{xi}=$ jumlah skor berdasarkan alternatif jawaban

$\sum x n \quad=j u m l a h$ skor total

Setelah diperoleh persentase dat, kemudian ditafsirkan dengan kriteria yang terdapat pada Tabel 2. Tabel 2 bersumber pada Koenjaraningrat (1990) dalam Syafrizal ( 2016)

Tabel 2. Kriteria Persentase Perilaku Konservasi

\begin{tabular}{cc}
\hline Persentase & Kategori \\
\hline $\mathbf{0}$ & Tidak ada \\
$\mathbf{1 - 2 5}$ & Sebagian kecil \\
$\mathbf{2 6 - 4 9}$ & Hampir separuhnya \\
$\mathbf{5 0}$ & Separuhnya \\
$\mathbf{5 1 - 7 5}$ & Lebih dari separuhnya \\
$\mathbf{7 6 - 9 9}$ & Hampir seluruhnya \\
$\mathbf{1 0 0}$ & Seluruhnya \\
\hline
\end{tabular}

\section{HASIL DAN PEMBAHASAN}

Berdasarkan penelitian yang telah dilakukan. Data hasil validasi LKPD dapat dilihat dari Tabel 3 .

Tabel 3. Hasil Perhitungan Data Validasi

\begin{tabular}{ccccc}
\hline No & Validator & Aspek yang diamati & Persentase & Kriteria \\
\hline 1 & Dosen biologi & Aspek materi & $84,29 \%$ & Sangat valid \\
& & Aspek kebahasaan & $86,67 \%$ & Sangat valid \\
2 & Guru IPA & Aspek materi & $82,86 \%$ & Sangat valid \\
& & Aspek kebahasaan & $80,00 \%$ & Sangat valid \\
\hline
\end{tabular}

Hasil kualitatif validasi LKPD menunjukkan kriteria "sangat valid" artinya kriteria sangat valid menunjukkan bahwa LKPD tersebut sudah layak untuk diuji coba dengan persentase hasil review oleh dosen biologi pada setiap aspek yakni $84,29 \%$ (untuk aspek materi) dengan kategori sangat valid, dan 86,67 \% (untuk aspek kebahasaan) dengan kategori sangat valid. Sebelum LKPD diimplementasikan, LKPD telah mengalami beberapi kali revisi sesuai dengan saran dari validator. Persentase hasil review dari guru IPA untuk aspek materi sebesar 82,86\% dengan kategori "sangat valid" dan aspek kebahasaan sebesar $80 \%$ dengan kategori "sangat valid". Setelah melakukan validasi LKPD dengan dosen biologi dan guru IPA SMP, peneliti malakukan uji keterbacaan LKPD 
kepada 15 sampel peserta didik kelas VIIA. Penilaian angket dilakukan untuk uji keterbacaan ini meliputi 4 aspek yakni aspek pembelajaran, aspek materi, aspek kegunaan, dan aspek tampilan. Hasil dari uji keterbacaan LKPD yang telah dikembangkan dapat dilihat dalam Tabel 4.

Tabel 4. Hasil Uji Keterbacaan LKPD

\begin{tabular}{ccc}
\hline $\begin{array}{c}\text { Aspek yang } \\
\text { Diamati }\end{array}$ & Nilai & Kriteria \\
\hline $\begin{array}{c}\text { Aspek } \\
\text { pembelajaran }\end{array}$ & $94,67 \%$ & Sangat valid \\
Aspek materi & $93,33 \%$ & Sangat valid \\
Aspek tampilan & $95,11 \%$ & Sangat valid \\
Aspek penggunaan & $96,00 \%$ & Sangat valid \\
\hline
\end{tabular}

Data hasil perhitungan kecenderungan berperilaku konservasi kura kura dapat dilihat dalam Tabel 5.

Tabel 5. Hasil Angket Kecenderungan Berperilaku Konservasi Kura-Kura

\begin{tabular}{cc}
\hline Angket kecenderungan berperilaku konservasi \\
\hline Persentase awal & $86,92 \%$ \\
Persentase akhir & $92.38 \%$ \\
Kesimpulan & Meningkat 5,46\% \\
\hline
\end{tabular}

Berdasarkan Tabel 5, kecenderungan berperilaku konservasi peserta didik pada saat pembelajaran di indoor 1 dan indoor 2, mengalami peningkatan perilaku konservasi kura-kura sebesar 5,46\%. Hasil perhitungan angket awal sebelum diberikannya LKPD adalah sebesar 86,92 \% dengan kriteria hampir seluruh peserta didik memiliki perilaku konservasi, dan perhitungan angket akhir setelah dilakukan pembelajaran dengan LKPD adalah sebesar $92.38 \%$ dengan kriteria hampir seluruh peserta didik memiliki perilaku konservasi. Dapat diartikan bahwa LKPD melalui pembelajaran dapat meningkatkan kecenderungan berperilaku konservasi kurakura bagi peserta didik SMP. Pengetahuan mengenai kura-kura yang didapat oleh peserta didik kelas VII A SMPN 17 Kota Bengkulu melalui pembelajaran menggunakan LKPD dapat meningkatkan perilaku konservasi peserta didik, hal ini sesuai dengan yang literatur yang menyebutkan bahwa pengetahuan dipandang sebagai sebuah tindakan yang bermakna untuk menganggulangi kendala psikologis seperti pengabaian dan kesalahan informasi. Dengan kata lain meskipun pengetahuan tidak memiliki efek langsung pada perilaku target itu sendiri namun pengetahuan menjadi mekanisme tersendiri yang memberi fasilitasi pada perubahan perilaku (Pratkanis dan Turner,1994; dalam Firmiana 2012). Lebih lanjut dalam Ruyani (2009), menyatakan bahwa pengetahuan merupakan faktor penting dalam mengembangkan beberapa sikap.

Pembelajaran mengenai kura-kura yang dikaitkan dengan materi interaksi makhluk hidup dengan lingkungan pada peserta didik SMP dimaksudkan untuk mengenalkan kura- kura agar terhindar dari kepunahan sebagaimana menurut Matthews dkk (2018), dengan mengadakan pengajaran kepada peserta didik untuk mengenal kurakura, habitat dan ancamannya secara lokal dan global, kita dapat melakukan upaya konservasi untuk melindungi kura-kura di dunia. Hal ini juga sejalan hasil penelitian yang dilakukan oleh Alif, dkk (2017) bahwa penggunaan bahan ajar yang bermuatan lingkungan seperti modul konservasi kurakura Sumatera dapat memberikan dampak yang positif terhadap pengetahuan konservasi siswa tentang kura-kura.

\section{PENUTUP}

\section{Simpulan}

Berdasarkan hasil perhitungan validasi Lembar Kerja Peserta Didik (LKPD) pada materi interaksi makhluk hidup dengan lingkungan, LKPD hasil pengembangan sangat layak diujicoba. Berdasarkan hasil pengisian angket kecenderungan berperilaku konservasi peserta didik melalui kegiatan IOI, LKPD hasil pengembangan efektif untuk meningkatkan kecenderungan berperilaku konservasi kurakura bagi peserta didik dari 86,92\% menjadi 92.38\% atau peningkatan sebesar 5,46 \% . 


\section{Saran}

Lembar kerja peserta didik ini dapat digunakan untuk penelitian tindakan kelas guna meningkatkan sikap ilmiah siswa dengan kegiatan pembelajaran outdoor.

\section{Daftar Pustaka}

Alif, Y.Z., Wiryono, Aceng R., Catherine, M. 2017. Pengetahuan Konservasi Pada Siswa SMA Dengan Pembelajaran IndoorOutdoor Menggunakan Modul Pendidikan Konservasi Kura-Kura. Prosiding Semirata BKS Bidang MIPA.

Anggraini, N., Hery, S, dan Aceng, R. 2017. Penggunaan Modul Pendidikan Konservasi Kura-Kura sebagai Upaya Meningkatkan Pengetahuan Konservasi Siswa SMP. (http://semirata2017. mipa. unja.ac.id.).

Asri, D. S. 2013. Tingkat Kepercayaan Diri Atlet dalam Pertandingan Kyorugi. Thesis. (http://www.respiratory.upi.edu./.pdf diakses tanggal 27 Februari 2018).

Astirin, O. K. 2000. Permasalahan Pengelolaan Keanekaragaman Hayati di Indonesia.(http://biodiversitas.mipa.u ns.ac.id/D/D0101/D010107.pdf. jurnal diakses pada 19 November 2017).

Firmiana, M.E, Rochimah I, Meithya R.P. 2012. "Go Green" Pelatihan untuk Mendorong Perilaku Konservasi Pro Lingkungan bagi Santri Al Ghazali, Kota Bogor. (http://www.jurnal.uac.ac.id/.pdf diakses tanggal 12 Mei 2018)

Iskandar,D.T. 2000.Kura-kura dan Buaya Indonesia dan Papua Nugini. ITB. Bandung

Kursini, M.D dan Yazid, M. 2005. Kura-kura Asia dalam Krisis dalam Warta Herpetofauna edisi 3. Bogor: ITB

Listriana, Ety T.D.C, Indriati N.H. 2012. Pngembangan Lembar Kegiatan Siswa (LKS) Berbantuan Media Manipulatif dengan
Pendekatan Inkuiri untuk Siswa SMP Kelas VIII Materi Lingkaran (http://www.online.um.ac.id/.pdf diakses tanggal 15 Mei 2018)

Matthews, C.E, Aceng R. . Green teacher "Timely Turtle Teaching". Issue 115. Canada. 2018

Prihatiningsih, N.A. 2017. Pengembangan LKS Melalui Kegiatan IOI (Indoor-OutdoorIndoor) untuk menilai Kognitif dan Kecenderungan Berperilaku Konservasi Kura-Kura Bagi Peserta didik.Bengkulu: FKIP UNIB

Qurniawan,T.F. 2010. Apakah Herpetogi dan Herpetofauna itu. (http:// herpetofauna.wordpress.com/2010/01/31 diakses pada 22 Januari 2018)

Robinson. 2013. Pengetahuan ,Sikap dan Perilaku Konservasi Hutan pada Peserta didik Sekolah Dasar di Sekitar Hutan Kawasan Gunung Salak Endah Taman Nasinal Gunung Halimun Salak.Skripsi.Bogor:IPB

Riduwan. 2015. Skala Pengukuran Variabel variabel Penelitian. Bandung: ALFABETA

Ruyani, A. 2009. Integrating the Message of Turtle Corservation into a Science Teaching Plan for Elementary School in Bengkulu City (http://www.asianturtlenetwork.org/librar $y /$ reports papers/Integrating message of turtle conservation into science teachin $\mathrm{g}$ in Bengkulu Indonesia Jan 2009.html diakses 14 Mei 2018)

Syafrizal, W. 2016. Hubungan antara Penguasaan Konsep Ekosistem dan sikap Peserta didik terhadap Konservasi Terumbu Karang di SMK Negeri Kelautan dan Perikanan Garut. Skripsi. (http://www. respiratory. upi.edu./.pdf diakses tanggal 27 Februari 2018)

Widalismana. 2012. Pengembangan Media Pembelajaran Berbasis Katalog untuk Meningkatkan Hasil Belajar Siswa pada Mata Pelajaran Ekonomi di SMA Negeri 5 Surakarta. (http://jurnal.fkip.uns..ac.id diakses pada tanggal 15 Mei 2018) 
Wiryono. Alif, Y.Z dan Yemie, S. 2016. Pendidikan Konservasi Kura-kura Sumatera. Bengkulu: Unit Penerbit FKIP UNIB. 